\title{
Ketangguhan Ruang Pusaka Saujana Danau Toba
}

\author{
Wahyu Utami1 ${ }^{1}$, Andalucia ${ }^{2}$, Rudolf Sitorus ${ }^{3}$, Basaria Thalarosa ${ }^{4}$ \\ 1-4 Dept. Arsitektur FT Universitas Sumatera Utara, Medan \\ wahyuutami2013@gmail.com
}

\begin{abstract}
ABSTRAK
Pusaka saujana Danau Toba adalah suatu sistem rangkaian bentang alam dan aktivitas masyarakat dalam kesatuan ruang yang tidak bisa terpisahkan. Kawasan pusaka saujana Danau Toba merupakan suatu kawasan dengan tata kehidupan masyarakat dalam bentang alam yang terdiri dari Danau Toba dan kalderanya serta bentang alamnya sebagai bagian dari proses geologis bentukan letusan gunung purba. Tahapan pembentukan ruang pusaka saujana dengan aktivitas budaya masyarakat tersebut sudah seharusnya menjadi fokus utama dalam proses keseimbangan perubahan bentang alam dengan kebutuhan tata ruang. Penelitian yang disusun berdasarkan dialog antara teori-teori yang memuat pariwisata di kawasan pusaka saujana dan ketangguhan ini mengambil studi kasus di Kawasan Pariwisata Pusaka Saujana Danau Toba. Metode yang digunakan adalah metode grounded research dengan penggalian teori dan kasusnya. Secara prinsip, tata ruang yang akan mengalami perubahan secara dinamis akibat dari pergerakan wisatawan dan perubahan pola pikir masyarakat setempat dalam menyikapi alam dan lingkungannya harus tetap mempertimbangkan tata nilai alam dan tata nilai sosial budaya masyarakat. Pariwisata yang dikembangkan harus selalu mengacu pada keseimbangan alam Danau Toba dan kalderanya dan keseimbangan tata nilai budaya masyarakat Batak. Ketangguhan dibutuhkan untuk mengantisipasi adanya perubahan agar tata ruang dan masyarakatnya mampu bertahan dengan kondisi yang ada.
\end{abstract}

Keywords: pusaka, saujana, ketangguhan, pariwisata

\section{ABSTRACT}

Cultural landscape heritage of Toba Lake Area is a series is a series of landscapes with community activities. It is about an area with its activities in a specific landscape that included by Toba Lake and its caldera with a landscape as a part of geology process into ancient eruption. Stage of cultural landscape process should be a significant focus for a balancing and equilibrium in environmental change. In this paper that supported by dialog theory between theories of tourism in cultural landscape area and resilience which take Toba Lake area as a case. Grounded research was used by cases exploration. Principally, spatial planning will be changing because of human activities and tourism activities. Changing in its livelihood was occurred because there were many demand for them. All the changes should be into a consideration for nature and livelihood with specific culture and belief. Tourism is set up with referring to equilibrium Toba Lake's nature and its communities of Batak ethic group. Resilience has a goal to anticipate many changing so as the spatial planning and the communities can adapt with its capacities.

Keywords: heritage, cultural landscape, resilience, tourism 


\section{Pendahuluan}

Suatu kawasan dengan ketahanan dalam kebencanaan mempunyai elemen yang saling terkait yaitu masyarakat sebagai komunitas aktif, tata ruang sebagai ruang kehidupan terbangun dan alam sebagai wadah dari ruang terbangun tersebut (Cumming, 2008). Ketiga aspek tersebut sudah seharusnya menjadi satu kesatuan yang tidak terpisahkan dan saling memberi dampak positif. Pada konteks kawasan bisa dijelaskan bahwa harus ada keseimbangan antara pembangunan fisik ruang dengan nilai atau peran alam sebagai wadah aktifitas masyarakatnya (Caniglia, Vallée, \& Frank, 2016; C. S. Holling, 1973; Plieninger \& Bieling, 2012). Keseimbangan tata ruang dengan aktivitas manusia di dalamnya tersebut dituangkan dalam SES (Social-Ecological System) yang memuat tentang resilience, vulnerability, adaptation dan robustness (Carpenter, Walker, Anderies, \& Abel, 2001; Cote \& Nightingale, 2011; Cumming, 2008, 2011; C Folke et al., 2010; Walker, Holling, Carpenter, \& Kinzig, 2004).

Pada konteks kawasan pusaka, Undang-Undang Cagar Budaya no 11 Tahun 2010 pusaka disebut dengan cagar budaya, sejarah suatu kawasan dengan bentang alam dan keseimbangan unsur-unsurnya merupakan suatu kesatuan sistem pengembangan tata ruang. Cagar budaya adalah warisan budaya bersifat kebendaan berupa benda cagar budaya, bangunan cagar budaya, struktur cagar budaya, situs cagar budaya dan kawasan cagar budaya di darat dan/atau di air yang perlu dilestarikan keberadaannya karena memiliki nilai penting bagi sejarah, ilmu pengetahuan, pendidikan, agama dan/atau kebudayaan melalui proses penetapan (Indonesia, 2010). Pendefinisian tersebut diolah kembali dengan istilah pusaka yang didalamnya memuat pusaka saujana yaitu dalam pernyataan pusaka Indonesia adalah pusaka alam, pusaka budaya, dan pusaka saujana; pusaka alam adalah bentukan alam yang istimewa; pusaka budaya adalah hasil cipta, rasa, karsa, dan karya yang istimewa dari lebih 500 suku bangsa di Tanah Air Indonesia, secara sendiri-sendiri, sebagai kesatuan bangsa Indonesia, dan dalam interaksinya dengan budaya lain sepanjang sejarah keberadaannya dan pusaka saujana adalah gabungan pusaka alam dan pusaka budaya dalam kesatuan ruang dan waktu (JPPI \& ICOMOS, 2003).

Suatu kawasan geografis tentunya mempunyai deretan sejarah perkembangan bentang alam dengan masing-masing mempunyai konsekuensinya (Hough, 1990; Utami, 2013b). Kawasan pusaka (heritage) merupakan suatu kawasan dengan identitas yang memiliki sejarah dan nilai-nilai yang terkandung didalamnya (Ashworth, 1991). Mengacu pada hal tersebut, setidaknya ada satu benang merah yang dapat ditarik bahwa pada saat melakukan pengembangan tata ruang kawasan, khususnya kawasan pariwisata pusaka (heritage tourism), alam sebagai wadah kegiatan yang akan selalu berkembang harus mempertimbangkan keberlanjutan tanpa harus merusak yang berakibat pada bencana alam yang sesungguhnya. Keberlanjutan tata ruang pariwisata pusaka dengan meminimalisir terjadinya kerusakan atau bencana bisa dipahami dengan pendekatan ketangguhan kawasan atau resilence. Bencana yang dimaksud adalah bencana alam dan bencana sosial yang terkait dengan tata nilai sosial budaya masyarakat. Pendekatan tersebut saat ini menjadi sangat krusial mengingat banyak kawasan pusaka yang dilirik menjadi kawasan pariwisata dengan berbagai program yang mendukung kunjungan wisatawan tanpa berpikir keberlanjutan lingkungan dan tata nilai sosial budaya masyarakatnya.

Pengembangan pariwisata yang hanya mengandalkan ledakan jumlah wisatawan dikhawatirkan akan menciptakan cekungan-cekungan budaya. Cekungan-cekungan budaya tersebut mencerminkan hilangnya nilai-nilai lokal karena adanya paradigm pariwisata yang selalu mengedepankan pelayanan wisatawan daripada mengembangkan keunikan fisik dan sosial budaya yang tentunya bisa memberi nilai yang lebih besar dari 
hanya sekedar angka kuantitatif. Tidak bisa dihindari, pengembangan pariwisata secara besar-besaran tanpa berpijak pada budaya lokal akan menghancurkan nilai budaya lokal yang dimulai dengan perubahan tata ruangnya. Perubahan ruang tersebut dikhawatirkan justru akan mengubah sistem ekologi tata ruang dan berdampak pada bencana alam dengan berbagai skala. Pada konsteks tersebut terdapat dua bencana yaitu bencana pada budaya dan bencana alam karena tata ruang buatan.

\section{Bahan dan Metode}

\section{$2.1 \quad$ Metode}

Metode yang dipakai dalam penelitian kualitatif rasionalitik ini adalah grounded research. Studi empirik dilakukan dengan penggalian data-data sejarah dan kondisi terkini yang mengacu pada teori ketangguhan pusaka saujana. Teori-teori pusaka saujana (cultural landscape) didialogkan dengan teori pariwisata (tourism) dan ketangguhan (resilience) untuk mendapatkan teori ketangguhan pusaka saujana untuk kawasan wisata. Setelah dilakukan dialog teori, tahap berikutnya adalah penyusunan preposisi yang digunakan di lapangan sebagai kaca mata dalam penggalian data-data dengan teknik eksplorasi. Fakta lapangan digali berdasarkan ketangguhan ruang alam dan kerentanan pada perubahan tata nilai, termasuk perubahan ruang di kawasan Danau Toba dan penumpukan aktivitas pariwisata.

\subsection{Ketangguhan dalam Teori Pusaka Saujana}

Interaksi masyarakat di dalam lingkungan alam dengan budayanya dijelaskan dalam ranah keilmuan cultural landscape (Droste, Plachter, \& Rossler, 1995; Sauer, 1925) yang dalam Bahasa Indonesia dikenal dengan saujana atau pusaka saujana (JPPI \& ICOMOS, 2003), sementara dalam undang-undang pelestarian disebut dengan cagar budaya gabungan alam dan budaya yang menggabungkan nilai alam dan fisiknya. Alam sebagai bentangan yang tidak melihat wilayah administrasi menjadi suatu penyatu bagi nilai-nilai alam dan budaya yang melekat (Hough, 1990; Robertson \& Richards, 2003; Sauer, 1925; Wilson \& Groth, 2003). Perkembangan kawasan sebagai suatu proses yang dinamis akibat dari interaksi manusia dengan budayanya pada lingkungan alamnya tersebut selalu menampilkan nilai-nilai penting yang menyatu dengan sistem yang telah terbentuk pada tahap-tahap sebelumnya (Utami, 2013b). Kondisi fisik tata ruang dengan kedinamisannya akan selalu menyesuaikan dengan tuntutan pola kehidupan, namun di satu sisi harus tetap mempunyai panduan yang kuat agar tidak terjadi kehancuran nilainilai yang sudah tertanam. Pemikiran dalam perubahan tata ruang yang terbentuk dipengaruhi oleh budaya (Rapoport, 1982; Sauer, 1925; Utami, 2013b, 2013a; Utami \& Andalucia, 2018) yang sedang berkembang sebagai bagian dari rekonstruksi budaya sebelumnya (Droste et al., 1995; Sauer, 1925) dan manusia tidak bisa melepaskan keberadaan alam sebagai suatu sinema yang bisa membentuk dan mengurai elemennya dengan karakter yang selanjutnya akan berproses kembali dengan keyakinan budaya masyarakat setempat.

Pusaka Saujana harus mampu sebagai pijakan dasar dari pengembangan pariwisata (Ashworth, 1991; Hough, 1990; Orbasli, 2000). Jika diabstraksikan teori pusaka saujana terkait erat dengan keseimbangan alam dan aktivitas manusianya. Hal ini sesuai dengan konsep utama di teori kota tangguh atau dalam bahasa Inggris dikenal dengan resilience city yang juga menekankan tentang keseimbangan (Adger Neil, 2000; C. Holling, 1996; C. S. Holling, 1973; S. Holling, 2001; Walker et al., 2004). Jika dalam ranah saujana atau cultural landscape keseimbangan menggunakan istilah balancing, dalam ranah ketangguhan atau resilience keseimbangan menggunakan istilah equilibrium. 
Resilience city banyak dijelaskan dalam beberapa buku yang berkaitan dengan ketahanan suatu kota (kawasan) dan keseimbangan untuk meminimalisir atau meniadakan dampak negatif adanya pertumbuhan suatu kota akibat dari ledakan jumlah penduduk dan tuntutan ruang. Dampak negatif tersebut selanjutnya dikenal dengan istilah bencana (disaster), yang meliputi bencana alam dan bencana sosial.

Terdapat beberapa istilah dalam kota tangguh atau resilience city (Pelling, 2003). yaitu antara lain (1) Risk; (2) Hazard ; (3) Vulnerability; (4) Physical vulnerability; (5) Social vulnerability; (6) Human vulnerability ; (7) Resilience dan (8) Disaster. Kota tangguh seperti dijelaskan Pelling (2003); Lokman (2016) dan Cumming (2008) dihubungkan dengan adanya kerentanan fisik dan sosial yaitu budaya manusianya yang dikhawatirkannya akan memunculkan bahaya bencana dan ketidakpahaman pada suatu bentang alam akan dapat berdampak munculnya bencana alam yang terencana (Cumming, 2008; Lokman, 2017; Pelling, 2003).

Perubahan bentang alam, landsekap banyak dipengaruhi oleh tuntutan ruang seperti dituliskan bahwa The implementation of infrastructures, such as dams and roads, has also led to landscape changes that range from small-scale land-use transformations to the emergence of wholly new environments at regional scales. The accumulated effects of these infrastructural interventions continue to change and alter ecosystems and material processes in foreseen and unforeseen ways" (Lokman, 2017). Dituliskan juga bahwa kerentanan suatu pengembangan wilayah kota dipengaruhi oleh lima aspek (Verde, 2013), kerentanan dengan ketidakseimbangan suatu tata ruang kota. Kelima aspek tersebut yaitu (1) population growth and geographical polarization; (2) Climate change; (3) Energy scarcity; (4) Governance dan (5) Environmental degradations (Verde, 2013).

Keterkaitan antara cultural landscape dengan resilience pada tata ruang dinyatakan sebagai satu kesatuan yang tidak terpisahkan (Plieninger \& Bieling, 2012). Kedua pendekatan tersebut saling terkait, khususnya cultural landscape sebagai dasar pengembangan pendekatan resilience city. Saujana adalah suatu keilmuan dengan pendekatan hubungan atau interaksi aktif pada alam sebagai nature dengan perilaku manusia sebagai culture dalam konteks penggunaan ruang fisik aktifitas manusia (Droste et al., 1995; Hough, 1990; Longstreth, 2008; Robertson \& Richards, 2003; Sauer, 1925; Utami, 2013b; Wilson \& Groth, 2003). Sementara dalam proses perubahan dinamis akibat dari interaksi aktif manusia pada alam terdapat suatu konsekuensi adanya perubahan landsekap dan budayanya yang harus bisa diantisipasi (Plieninger \& Bieling, 2012).

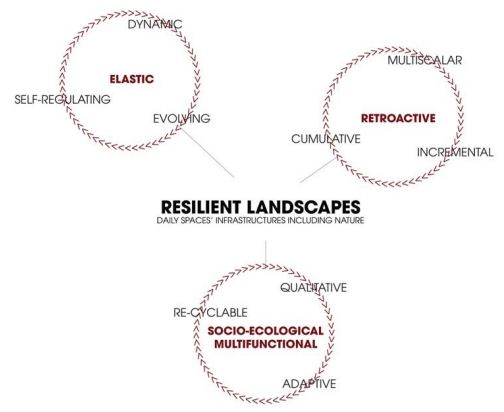

Gambar 1. Resilience Landscape Circle

(Sumber: Plieninger and Bieling, 2012)

Perubahan kawasan dengan diiringi perubahan landsekap yang sangat cepat salah satunya adalah kawasan pariwisata khususnya kawasan pariwisata pusaka saujana (cultural landscape heritage tourism). Ketangguhan kawasan pariwisata pusaka saujana yang sesuai dengan pendekatan ketangguhan adalah pendekatan pariwisata yang tetap berpijak pada kemampuan dan atau daya dukung lingkungan dan masyarakatnya. 
Pariwisata tetap akan bisa maksimal dengan tetap berbasis potensi utama kawasan yang bersumber dari konsep cagar budaya atau pusaka (Ashworth, 1991). Di satu sisi ledakan jumlah wisatawan akan mengakibatkan titik jenuh kawasan dan berakibat pada perubahan tata ruang secara besar-besaran sehingga dibutuhkan pembaharuan pemahaman eksistensi wisatawan dalam konsep pariwisata (Butler, 2017; Caniglia et al., 2016; Hall, Prayag, \& Amore, 2018; Orbasli, 2000). Ketangguhan kawasan pariwisata pusaka akibat dari kegiatan wisatawan diuraikan dalam istilah sustainability, capacity dan resilience (Butler, 2017).

Untuk mengembangkan istilah ketangguhan, Cumming (2011) dan penulis lainnya sebenarnya mengacu pada teori Holling (1973) yang menjelaskan bahwa ketangguhan terkait dengan keseimbangan (equilibrium), keseimbangan sosial budaya dan lingkungan alamnya atau yang lebih dikenal dengan SES (Social-Ecological System). Dibawah ini terdapat beberapa definisi tentang ketangguhan, antara lain yaitu :

1. resilience determines the persistence of relationships within a system and is a measure of the ability of these systems to absorb change of state variables, driving variables and parameters and still persist; resilience is the property of system and persistence pr probability of extinction is the result (C. S. Holling, 1973)

2. resilience is the buffer capacity of a system, the ability of the system to absorb perturbations (Adger Neil, 2000)

3. resilience is the capacity to adjust to threats and mitigate or avoid harm (Pelling, 2003)

4. resilience is a concept that has advanced in relation to the dynamic development of complex adaptive systems with interactions across temporal and spatial scales (Carl Folke, 2006)

5. resilience refers to the deal with disturbances or change without altering the essential characteristic of the system in question (Plieninger \& Bieling, 2012)

6. resilience is the capability of systems and individuals to cope with significant adversity or risk (UNESCO, 2017)

7. resilience is the ability of communities to survive in difficult circumtances, small remote or insular communities (Butler, 2017)

\section{Hasil dan Diskusi}

\subsection{Pusaka Saujana Danau Toba}

Danau Toba dengan Pulau Samosir yang ada didalamnya serta kaldera yang mengelilinginya tidak bisa dilepaskan dengan konsep keseluruhan yang termuat dalam proses tahunan bahkan puluhan ribu tahun yang lalu, yaitu proses geologis terbentuknya Danau Toba dan kalderanya. Sejarah menjelaskan bahwa Danau Toba merupakan bentukan dari fenomena alam yang terjadi karena letusan gunung yang kemudian seiring dengan waktu, bentang alam yang terbentuk menjadi tempat kehidupan masyarakat yaitu masyarakat suku Batak. Pergerakan masyarakat suku Batak dengan salah satunya Pusuk Buhit yang dipercaya sebagai awal muka kehidupan di sekitar Pulau Samosir dan sekeliling danau terluar, telah menjadikan bentang alam tidak hanya sebagai benteng bagi danau, namun juga sebagai tempat bermukim. 


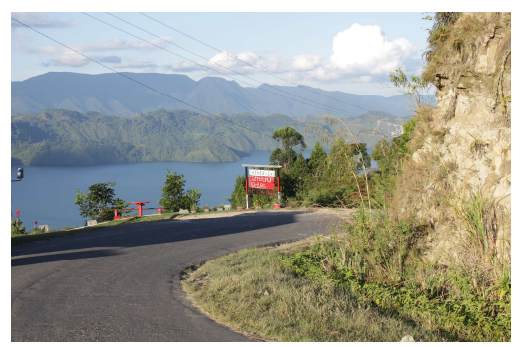

Gambar 2. Kondisi Danau Toba dan sekelilingnya

(Sumber: Survey, 2017, 2018)

Bentang alam yang unik dengan proses panjang sejarah didalamnya telah membentuk berbagai aktivitas masyarakat yang terorientasi dengan alamnya yang kemudian dalam paper ini disebut dengan pusaka saujana Danau Toba. Definisi tersebut mengacu pada uraian istilah pusaka saujana atau cultural landscape sebagai hasil dari interaksi manusia dengan budayanya dalam menyikapi alam dan proses perubahan alamnya (Robertson \& Richards, 2003; Sauer, 1925; Utami, 2013a, 2013b; Utami \& Andalucia, 2018; Wilson \& Groth, 2003). Aktivitas sebagai bentukan dari interaksi yang secara umum terbagi menjadi dua ruang yaitu sebagai tempat tinggal dan sebagai pendukung keseharian hidup masyarakatnya, misalnya ladang, hutan, tepian danau atau bahkan danau itu sendiri. Ruang pendukung tersebutlah yang menjadi salah satu keunikan masyarakat yaitu bagaimana masyarakat bisa menyikapi ruang yang ada, tanpa mengubah secara berlebihan. Pada proses tersebut mengandung artian bahwa ada suatu proses dinamis baik alam dan tata nilai sosial budaya manusia dalam menyikapi kebutuhan ruang.
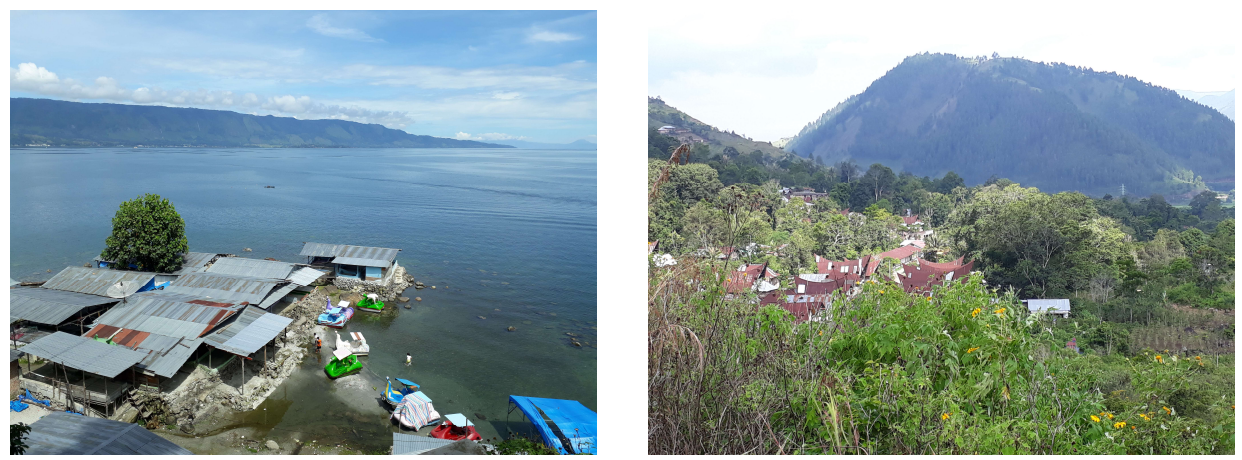

Gambar 3. Permukiman dan Ruang Aktivitas di Kawasan Danau Toba

(Sumber: Survey, 2018)

Aktivitas masyarakat akan sangat dipengaruhi oleh bentukan alam dengan melakukan beberapa perubahan yang bertanggungjawab untuk menyesuaikan kebutuhannya (Utami, 2013b) yang tercermin dalam pusaka saujana Danau Toba dengan masyarakat Batak yang memiliki tata nilai tersendiri dalam menyikapi bentuk kaldera dan bentang alam pendukungnya sebagai bentukan dari letusan gunung termasuk menyikapi keberadaan Danau Toba itu sendiri. Lembah-lembah bentukan dari kaldera yang menjadi daerah tempat tinggal dan tempat beraktivitas masyarakat Batak juga merupakan cerminan dari interaksi manusia terhadap bentang alam yang sudah terbentuk. Ruang-ruang yang ada saat ini di kawasan Danau Toba yang meliputi tujuh kabupaten yang mengelilinginya adalah ruang intepretasi dalam menyikapi bentukan alam dengan tingkat kebutuhan ruangnya. Kondisi tersebut mengacu pada ruang fisik sebagai hasil interaksi dengan keunikan tata nilai berdasarkan bentuk bentang alamnya masing-masing (Calcatinge, 2013; Utami, 2013a, 2015, 2017; Utami \& Andalucia, 2018). 
Perubahan tersebut juga terjadi pada kawasan Danau Toba yang seiring dengan waktu berubah sesuai dengan kebutuhan ruang masyarakat.

Danau sebagai bentukan utama dalam ruang pusaka saujana Danau Toba telah didukung dengan keberadaan kaldera-kalderanya yang tersusun oleh bukit, lereng bukit, lembah bukit, tepian danau serta pulau-pulau kecil penyertanya. Kesemuanya itu dengan diisi aktivitas masyarakat dengan masing-masing bentukan telah membentuk pusaka saujana Danau Toba yang sudah ada ratusan tahun bahkan ribuan tahun yang lalu dengan perubahan di masing-masing periode waktu.

\subsection{Ketangguhan Ruang Pusaka Saujana Danau Toba}

Danau Toba dan kawasan di sekitarnya yang awalnya hanya sebagai tempat memuja (khususnya Pusuk Buhit) dan tempat bermukim, karena kondisi alamnya yang sangat mendukung pada akhirnya dijadikan tujuan wisata selain juga menjadi lahan produksi makanan karena kesuburannya. Namun tanpa disadari, pengembangan pariwisata yang sudah ada tidak semuanya mampu mendukung keseimbangan lingkungan, seperti yang sudah dijelaskan dalam teorinya Holling (1973) dan Cumming (2011) tentang pentingnya keseimbangan dan ketangguhan dalam pengembangan tata ruang kawasan, atau dalam teorinya Butler (2017) yang menjelaskan tentang peran pariwisata yang merusak lingkungan alam dan tata nilai sosial budayanya.

Berbagai program terkait pariwisata sudah banyak dilakukan di kawasan Danau Toba, terutama setelah dipilihnya Kawasan Danau Toba sebagai salah satu dari sepuluh Destinasi Wisata Nasional. Perbaikan dan penambahan infrastruktur banyak dilakukan namun tidak secara holistik pelaksanaannya, karena tetap hanya terfokus pada beberapa titik tertentu saja. Ruang-ruang secara bersamaan menggeliat mengikuti program tersebut, baik sebagai bagian dari program pemerintah maupun gerakan dari masingmasing komunitas masyarakat. Melihat fenomena tersebut, bisa dijelaskan bahwa saat ini mulai banyak bermunculan ruang-ruang baru hasil dari pembukaan lahan ataupun penggerusan lahan-lahan lereng perbukitan untuk mendukung gerakan pariwisata.

Gerakan yang membabi buta dalam peningkatan bidang pariwisata tersebut tentunya sangat membahayakan bagi kelangsungan ruang pusaka saujana Danau Toba. Hal ini seperti uraian bahwa suatu kawasan pariwisata harus memikirkan kapasitas dan daya dukung kawasan agar aktivitas yang ada tidak merusak keseimbangan alam dan tata nilai budaya masyarakat. Kapasitas atau capacity (Butler, 2017; Hall et al., 2018; Luthe \& Wyss, 2014; Walker et al., 2004) merupakan kunci utama dalam konsep ketangguhan untuk mendukung kemampuan atau ability (Butler, 2017; Hall et al., 2018; C. S. Holling, 1973; S. Holling, 2001; Walker et al., 2004) dalam bertahan pada suatu kerentanan perubahan yang bisa dimunculkan dari adanya program-program kegiatan wisatawan di Kawasan Danau Toba. Banyak penambahan fasilitas dan infrastruktur yang tidak mengindahkan nilai alam dan budaya masyarakat setempat. Resort, hotel, bar-bar dan ruang-ruang baru mulai bermunculan seiring dengan wisatawan banyak berdatangan dan menuntut adanya fasilitas tersebut. Penambahan jalan yang mulai dilakukan untuk akses di semua ruang khususnya di Pulau Samosir serta pembentukan ruang-ruang baru dikhawatirkan akan merusak nilai-nilai ruang yang sudah terbentuk ratusan bahkan ribuan tahun yang lalu. 


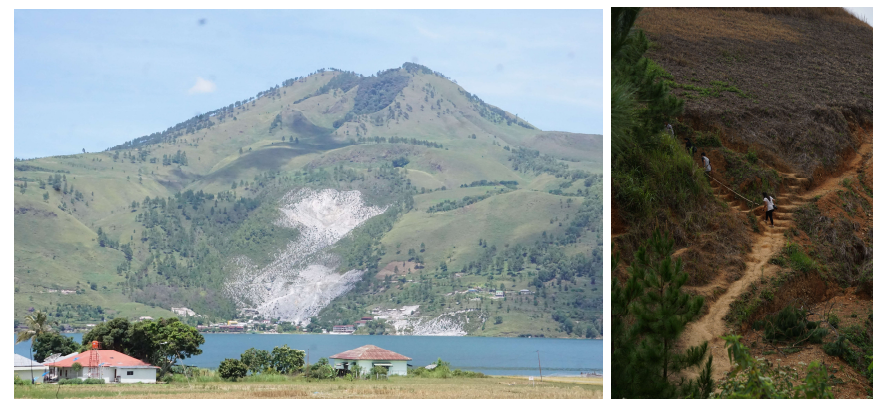

Gambar 4. Pusuk Buhit sebagai Sasaran Wisata Baru dan Pola Pembentukan Ruang Baru sebagai Fasilitas Wisata

(Sumber: survey, 2018)

Kondisi perairan Danau Toba yang saat ini mengelilingi Pulau Samosir dengan kaldera yang ada sudah seharusnya menjadi pemikiran utama dalam mengembangkan pariwisata yang berbasis nilai ruang dan lingkungannya. Kawasan Danau Toba harus memikirkan ketangguhan pusaka saujana yang ditujukan pada keseimbangan alam dan lingkungannya serta ketangguhan masyarakat dalam menyikapi ledakan jumlah wisatawan yang membutuhkan fasilitas pendukung dan yang berpeluang mengubah tata nilai masyarakatnya.

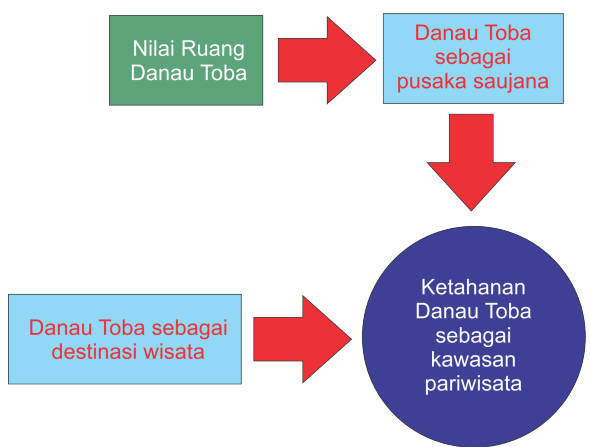

Gambar 5. Konsep Ketangguhan Danau Toba dan kawasan sekitar sebagai destinasi pariwisata nasional

(Sumber : Analisa, 2018)

\section{Simpulan}

Kawasan Danau Toba sebagai salah satu kawasan pariwisata nasional yang meliputi kaldera dengan bentang lahannya serta danau Tobanya sendiri merupakan pusaka saujana yang sudah seharusnya memiliki pertimbangan tata ruang tangguh dalam pengembangan kawasannya. Kawasan pusaka saujana Danau Toba adalah suatu kawasan dengan tata kehidupan masyarakat dalam bentang alam yang tersusun oleh Danau Toba dan kalderanya serta bentang alamnya sebagai bagian dari proses geologis bentukan letusan gunung purba. Sejarah panjang proses pembentukan bentang alam dengan keunikan tata kehidupan masyarakat dalam pengelolaannya menjadi keunikan tersendiri sebagai kawasan pusaka saujana Danau Toba. Hal ini juga didukung dengan adanya keunikan dan kekhasan bentang alam dan aktivitas masyarakat Batak dalam membentuk permukiman dan fungsi ruang pendukung untuk aktivitas kehidupannya. Bertumpu pada kondisi tersebut, sejak dulu kawasan Danau Toba telah dikembangkan sebagai kawasan wisata pusaka saujana yang mengedepankan keunggulan bentang alam dan tata kehidupan masyarakatnya tanpa menanggalkan kedinamisanya perubahan pola pehidupan masyarakat. Adanya wisatawan dengan penumpukan aktivitasnya diharapkan tidak akan mengganggu kesenambungan atau keseimbangan alam sebagai wadah 
berkegiatan dan tata nilai masyarakat sebagai identitas diri. Kemampuan alam dan masyarakat pada kapasitas yang sesuai akan tetap menjadikan ruang pusaka saujana Danau Toba sebagai ruang yang nyaman. Ketangguhan dalam menyikapi tuntutan ruang pariwisata dikembalikan pada dasar-dasar ruang pusaka dan pelestariannya yaitu dengan tetap menjadikan alam dan bentang alamnya sebagai inspirasi dalam pembentukan ruang serta menjadikan nilai tata kehidupan yang sudah turun temurun sebagai pedoman dalam mengendalikan ruangnya. Tanpa mempertimbangkan kedua hal tersebut, tata ruang akan rusak dan tidak seimbang yang tentunya akan berdampak pada bencana alam ataupun bencana sosial. Potensi yang ada harus dikembangkan berdasarkan kondisi alam, bentang alam serta kehidupan masyarakat setempat sehingga potensi-potensi tersebut akan selalu terwariskan dan terpelihara.

\section{Ucapan Terima Kasih}

Terima kasih diucapkan kepada Pendanaan DPRM Dirjen dikti Tahun Anggaran 2018 yang telah memberikan pendanan dalam penelitian terkait Pusaka Danau Toba dengan pendekatan teori cultural landscape dan resilience city.

\section{Daftar Pustaka}

Adger Neil, W. (2000). Social and ecological resilience: are they related? Progress in Human Geography, 24(3), 347-364.

Ashworth, G. J. (1991). Heritage planning: Conservation as the management of urban change. Groningen: Geo Pers, Netherlands.

Butler, R. (2017). Tourism and Resilience. Oxfordshire, UK: CAB International.

Calcatinge. (2013). The Need for A Cultural Landscape Theory, An Architect Approach. Zerich: LIT Verlag GmbH \& co.KG Wien.

Caniglia, B. S., Vallée, M., \& Frank, B. (2016). Resilience, environmental justice and the city. Resilience, Environmental Justice and the City.

Carpenter, S., Walker, B., Anderies, J. M., \& Abel, N. (2001). From Metaphor to Measurement: Resilience of What to What? Ecosystems, 4(8), 765-781.

Cote, M., \& Nightingale, A. J. (2011). Resilience thinking meets social theory. Progress in Human Geography, 36(4), 475-489. https://doi.org/10.1177/0309132511425708

Cumming, G. S. (2008). Spatial Resilience in Social-Ecological Systems. Cape Town: Springer.

Cumming, G. S. (2011). Spatial resilience: Integrating landscape ecology, resilience, and sustainability. Landscape Ecology, 26(7), 899-909.

Droste, B. von, Plachter, H., \& Rossler, M. (1995). Cultural landscapes of universal value: components of a global strategy. Book. Stuttgart, New York: Gustav Fischer Verlag Jena.

Folke, C. (2006). Resilience: The emergence of a perspective for social-ecological systems analyses. Global Environmental Change, 16(3), 253-267.

Folke, C., Carpenter, S. R., Walker, B., Scheffer, M., Chapin, T., \& Rockstrom, J. (2010). Resilience Thinking: Integrating Resilience, Adaptability and Transformability. Ecology and Society, 15(4), 419-420.

Hall, C. M., Prayag, G., \& Amore, A. (2018). Tourism And Resilience. Individual, Organisational And Destination Perspectives. Channel View Publications.

Holling, C. (1996). Engineering Resilience versus Ecological Resilience. Engineering Within Ecological Constraints, (1996), 31-43. Retrieved from

Holling, C. S. (1973). Resilience and Stability of Ecological Systems. Annual Review of Ecology and Systematics, 4(1973), 1-23.

Holling, S. (2001). Understanding the Complexity of Economic, and Ecological, Social 
System. Ecosystem, 4(5), 390-405.

Hough, M. (1990). Out of Place: Restoring Identity to the Regional Landscape. New Heaven and London: Yale University Press.

Indonesia, P. R. (2010). Undang-Undang Cagar Budaya. Undang-Undang Republik Indonesia Nomor 11 Tahun 2010 Tentang Cagar Budaya.

JPPI \& ICOMOS. (2003). Piagam Pelestarian Pusaka Indonesia - Indonesian Charter for Heritage Conservation, 1-4.

Lokman, K. (2017). Cyborg landscapes: Choreographing resilient interactions between infrastructure, ecology, and society. Journal of Landscape Architecture, 12(1), 60-73.

Longstreth, R. (2008). Cultural Landscapes: Balancing Nature and Heritage in Preservation Practice. University of Minnesota Press (Vol. 63). University of Minnesota Press.

Luthe, T., \& Wyss, R. (2014). Assessing and planning resilience in tourism. Tourism Management, 44, 161-163.

Orbasli, A. (2000). Tourists in Heritage Town: Urban Conservation and Heritage Management.

Pelling, M. (2003). The Vulnerability of Cities Natural Disasters and Social Resilience. Earthscan. London.

Plieninger, T., \& Bieling, C. (2012). Resilience and the Cultural Landscape. Understanding and Managing Change in Human-Shaped Environments. Cambridge, UK: Cambridge University Press.

Rapoport, A. (1982). The meaning of the built environment. A Non Verbal Communication Approach. Habitat International (Vol. 8). Sage Publication.

Robertson, I., \& Richards, P. (2003). Studying Cultural Landscapes. New York: Oxford University Press Inc.

Sauer, C. O. (1925). Morphology of Landscape. In Human Geography: An Essensial Anthology, 1995 (Vol. 2, pp. 19-54). Blackwell Publishing.

Utami, W. (2013a). Dialog Teoritik "Saujana" dalam Ranah Ilmu Arsitektur dan Perencanaan. Koridor, 2, 1-6.

Utami, W. (2013b). Konsep Saujana Kota Magelang. Universitas Gadjah Mada.

Utami, W. (2015). Comparing The Cultural Landscape's Concept. Case Study: Managing Data for A Smart City in Indonesia. In International conference for spatial planning and sustainable development, 2015 (pp. 1-11).

Utami, W. (2017). Balancing Old and New for Heritage in Indonesia . Cultural Landscape and National Tourism Destination Program in Toba Lake ,. In International conference for spatial planning and sustainable development (pp. 1-11).

Utami, W., \& Andalucia. (2018). Ruang Pusaka Saujana Danau Toba. In IPLBI 2018 (pp. 56-63). Semarang, Indonesia: IPLBI.

Verde, A. (2013). Resilient Landscapes. From spontaneous adaptation to a post-industrial planned multi-scalar resilience. Resilient Cities 2013 Congress, 4th Global Forum on Urban Resilience \& Adaptation.

Walker, B., Holling, C. S., Carpenter, S. R., \& Kinzig, A. (2004). Resilience, adaptability and transformability in social-ecological systems. Ecology and Society, 9(2).

Wilson, C., \& Groth, P. (2003). Everyday America. Cultural Landscape Studies after J. B. Jackson. Berkeley Los Angeles London : University of California Press. 